Comment

\title{
Comment on Khanal et al. The Repertoire of Adenovirus in Human Disease: The Innocuous to the Deadly. Biomedicines 2018, 6, 30
}

\author{
Richard L. Atkinson (D) \\ Virginia Commonwealth University School of Medicine, Richmond, VA 23103, USA; adv36lab@gmail.com; \\ Tel.: +1-804-244-9070
}

Received: 12 December 2018; Accepted: 17 January 2019; Published: 22 January 2019

\begin{abstract}
In their comprehensive review on adenoviruses, Khanal et al. omitted obesity as a disease caused by adenovirus 36 (Adv36). Animal studies have shown that experimental infection with Adv36 causes increased adiposity, and human association studies have shown that prior infection with Adv36 is correlated with greater body weight in humans in multiple countries of the world.
\end{abstract}

Keywords: Adenovirus 36; obesity; etiology

\section{Comment}

The paper in Biomedicines by Khanal et al. [1] reviewing diseases due to adenoviruses is comprehensive, but the authors left out one disease that is the most prevalent in the US and perhaps the world-obesity. Multiple studies have shown that adenovirus 36 (Adv36) causes obesity when experimentally administered to animals [2-4]. Chickens, mice, rats, and monkeys that are infected with Adv36 increase adiposity by $50 \%$ to $150 \%$, and $60 \%$ to $100 \%$ of infected animals become obese [2,3]. Monkeys were shown to have increased body fat by about $60 \%$ in $100 \%$ of infected animals over a 7-month period [3]. For ethical reasons, humans cannot be experimentally infected, but multiple studies in humans assessing prior infection indicated by the presence of antibodies to Adv36 have concluded that Adv36 is associated with obesity [5-7]. The prevalence of Adv36 infection in adults and children with obesity throughout the world averages about $30 \%$, but has a wide range $[5,7]$. Infection rates in non-obese individuals are lower [5,7]. Since Adv36 was first identified in 1978 and the worldwide epidemic of obesity began about 1980, it may be reasonable to postulate that Adv36 is responsible for about half of the increase in obesity since 1980. Na et al. [4] demonstrated that an anti-Adv36 vaccine prevented obesity in infected mice. Perhaps a large percentage of obesity in the world can be prevented by a vaccine.

\section{References}

1. Khanal, S.; Ghimire, P.; Dhamoon, A.S. The Repertoire of Adenovirus in Human Disease: The Innocuous to the Deadly. Biomedicines. 2018, 6, 30. [CrossRef]

2. Dhurandhar, N.V.; Israel, B.A.; Kolesar, J.M.; Mayhew, G.F.; Cook, M.E.; Atkinson, R.L. Increased adiposity in animals due to a human virus. Int. J. Obes. Relat. Metab. Disord. 2000, 24, 989-996. [CrossRef]

3. Dhurandhar, N.V.; Whigham, L.D.; Abbott, D.H.; Schultz-Darken, N.J.; Israel, B.A.; Bradley, S.M.; Kemnitz, J.W.; Allison, D.B.; Atkinson, R.L. Human adenovirus Ad-36 promotes weight gain in male rhesus and marmoset monkeys. J. Nutr. 2002, 132, 3155-3160. [CrossRef]

4. Na, H.N.; Nam, J.H. Proof-of-concept for a virus-induced obesity vaccine; vaccination against the obesity agent adenovirus 36. Int. J. Obes. 2014. [CrossRef] 
5. Atkinson, R.L.; Dhurandhar, N.V.; Allison, D.B.; Bowen, R.L.; Israel, B.A.; Albu, J.B.; Augustus, A.S. Human adenovirus-36 is associated with increased body weight and paradoxical reduction of serum lipids. Int. J. Obes. 2005, 29, 281-286. [CrossRef] [PubMed]

6. Aldhoon-Hainerová, I.; Zamrazilová, H.; Atkinson, R.L.; Dušátková, L.; Sedlácková, B.; Hlavatý, P.; Lee, Z.P.; Kunešová, M.; Hainer, V. Clinical and laboratory characteristics of 1179 Czech adolescents evaluated for antibodies to human adenovirus 36. Int. J. Obes. 2014, 38, 285-291. [CrossRef] [PubMed]

7. Xu, M.Y.; Cao, B.; Wang, D.F.; Guo, J.H.; Chen, K.L.; Shi, M.; Yin, J.; Lu, Q.B. Human Adenovirus 36 Infection Increased the Risk of Obesity: A Meta-Analysis Update. Medicine (Baltimore). 2015, 94, e2357. [CrossRef] [PubMed]

(C) 2019 by the author. Licensee MDPI, Basel, Switzerland. This article is an open access article distributed under the terms and conditions of the Creative Commons Attribution (CC BY) license (http:/ / creativecommons.org/licenses/by/4.0/). 